\title{
Making Technological Innovation Work for Sustainable Development
}

\section{Citation}

Diaz Anadon, Laura, Gabriel Chan, Alicia Harley, Kira Matus, Suerie Moon, Sharmila L. Murthy, William C. Clark. 2015. Making Technological Innovation Work for Sustainable Development. HKS Faculty Research Working Paper Series RWP15-079, Harvard University.

\section{Published Version}

doi: 10.1073/pnas.1525004113;10.1073/pnas.1525004113

\section{Permanent link}

http://nrs.harvard.edu/urn-3:HUL.InstRepos:24890837

\section{Terms of Use}

This article was downloaded from Harvard University's DASH repository, and is made available under the terms and conditions applicable to Other Posted Material, as set forth at http:// nrs.harvard.edu/urn-3:HUL.InstRepos:dash.current.terms-of-use\#LAA

\section{Share Your Story}

The Harvard community has made this article openly available.

Please share how this access benefits you. Submit a story.

Accessibility 


\section{Making Technological Innovation Work for Sustainable Development}

Laura Diaz Anadon $^{\mathrm{a}, \mathrm{b}, 1}$, Gabriel Chan ${ }^{\mathrm{c}, 1}$, Alicia Harley ${ }^{\mathrm{a}, 1}$, Kira Matus ${ }^{\mathrm{b}}$, Suerie Moon ${ }^{\mathrm{a}, \mathrm{d}, 2}$, Sharmila L. Murthy ${ }^{\mathrm{e}}$, William C. Clark ${ }^{\mathrm{a}}$

${ }^{a}$ Harvard Kennedy School of Government, Harvard University, Cambridge, MA 02138

${ }^{\mathrm{b}}$ Department of Science, Technology, Engineering and Public Policy, University College London, London, UK

${ }^{c}$ Humphrey School of Public Affairs, University of Minnesota, Minneapolis, MN 55455

${ }^{\mathrm{d}}$ Harvard T.H. Chan School of Public Health, Harvard University, Boston, MA 02115

${ }^{\text {e }}$ Suffolk University Law School, Suffolk University, Boston, MA 02108

Author contributions: L.D.A., G.C., A.H., K.M., S.M., S.L.M., and W.C. wrote the paper.

The authors declare no conflict of interest.

${ }^{1}$ L.D.A., G.C., and A.H. contributed equally to this work.

${ }^{2}$ To whom correspondence may be addressed. E-mail smoon@hsph.harvard.edu. 


\begin{abstract}
Sustainable development requires harnessing technological innovation to improve human well-being in current and future generations. However, poor, marginalized, and unborn populations too often lack the economic or political power to shape innovation processes to meet their needs. Issues arise at all stages of innovation, from invention of a technology through its selection, production, adaptation, adoption, and retirement. Three insights should inform efforts to intervene in innovation systems for sustainable development. First, innovation is not a linear process but rather a complex adaptive system involving many actors and institutions operating simultaneously from local to global levels; interventions must take this complexity into account. Second, there has been significant experimentation in mobilizing technology for sustainable development in the health, energy, and agriculture sectors, among others, but learning from past experience requires structured cross-sectoral comparisons and recognition of the socio-technical nature of innovation. Third, the current constellation of rules, norms, and incentives shaping innovation is not always aligned towards sustainable development. Past experience demonstrates that it is possible to reform these institutions, and the imperative of harnessing innovation for sustainable development makes it necessary to do so. Many actors have the power to re-orient innovation systems towards sustainable development through research, advocacy, training, convening, policymaking, and financing. We offer three proposals to begin: mobilizing global financing to invest in inventing suitable and affordable technologies to meet sustainable development objectives; developing measures to engage marginalized populations systematically through all stages of the innovation process; and establishing channels for regularized learning across domains of practice.
\end{abstract}

Keywords: sustainable development, technology, innovation systems, complex adaptive systems, knowledge systems

\title{
Significance Statement
}

The 2015 UN Sustainable Development Goals and Paris Agreement on climate change heightened global attention to sustainable development. Innovation in technologies such as cleaner energy production or water-saving agricultural practices will be crucial for meeting these commitments. However, unless we change the rules and incentives shaping innovation processes, we will continue to face problems such as inadequate investment in research and development for technologies addressing problems that affect the poor, products not affordable or suitable for use in low-income settings, or technologies that improve well-being today but place an unacceptable burden on future generations. This Perspective identifies the fundamental reasons why current innovation systems fall short, what needs to change, and offers several proposals to begin making such change. 
Technological innovation is at the heart of sustainable development. In September 2015, following an extensive multi-year negotiation among governments, 193 countries of the United Nations drafted the 2030 Agenda for Sustainable Development, which makes explicit a set of 17 Sustainable Development Goals (SDGs). Innovation in its own right is posited as one of the SDGs (Goal 9) and also as a means to achieving the other SDGs ${ }^{1}$. While technological innovation holds great promise to enable sustainable development, it also possesses the potential to erode human well-being. For example, technologies to utilize energy from fossil fuels have exacerbated global climate change; agricultural practices that place a heavy reliance on pesticides and fertilizers have degraded the long-run productivity of farmland; and the widespread use of antimicrobial drugs in animal husbandry has bred resistance that may render these drugs ineffective in both livestock and humans. The tremendous capacity of technological innovation to positively or negatively affect human well-being places the system of rules and incentives that guide technological innovation at the center of the sustainable development challenge.

Harnessing technological innovation for sustainable development requires a broad view of technology and innovation. Technology includes the full range of devices, methods, processes, and practices (2). Innovation is a multi-faceted system comprised of targeted goals, the technologies needed to reach those goals, the people and organizations who act within the system, and the rules and incentives that shape the processes of innovation from invention through the use and eventual retirement of technologies (3-5). In parallel with broader globalization trends, innovation systems increasingly operate across decisionmaking levels, from local communities to the global arena, involving actors, rules, and norms that cross or transcend borders.

Sustainable development seeks to simultaneously advance inter-generational and intra-generational equity, which poses a specific set of challenges for innovation systems beyond those applicable to either dimension of equity alone. The existing actors, norms, and policies shaping innovation processes perpetuate intra-generational inequity by failing to compensate for the unequal distribution of economic and political power around the world, within and between communities and nations. For example, global investment in research and development $(\mathrm{R} \& \mathrm{D})$ to develop medicines for "neglected diseases" is inadequate because the developing country populations that would benefit the most from such technologies are not well-positioned to incent such investment (6). Inadequate voice to shape innovation processes may stem from a lack of political power, poor access to communication networks, or insufficient financial resources $(7,8)$. Further, future generations do not have the political or economic power to compel present generations to shape innovation systems to meet inter-generational equity goals.

The perpetuation of inequities is particularly persistent when mediated over the natural environment (e.g. biodiversity loss) and across networks of unequal power (e.g. gender inequality), where market and other forms of system failure are pervasive. This is exemplified clearly by the problem of global climate change, caused by greenhouse gas emissions that accrue cumulatively and persist for several generations; the future generations impacted by current emissions are unable to advocate for changes to present behavior. Sustainable development must consider intra-generational equity in the context of intergenerational equity; improving equity on one dimension may not necessarily advance the other and they may in fact conflict (9). Even when technologies that hold great potential for sustainable development

\footnotetext{
${ }^{1}$ The importance of technological innovation is reflected in the frequency with which it appears in the final SDG document: 47 times for "technology/technological” and 27 times for "innovation/innovative." (1)
} 
become affordable and globally accessible, they may not be suitable to meet needs in the local contexts where they could be used (10).

How should policies and interventions be designed to realize the potential contributions of technology for sustainable development? Many questions remain unanswered about where the problems lie, let alone what is to be done. What institutional reforms are needed at sub-national, national, and global decisionmaking levels? How can different actors working at these levels leverage technologies to effect change on implementation on the ground? What approaches are most effective for different types of technologies and social contexts?

Making technologies work for sustainable development will require greater clarity in conceptualizing the innovation process itself, in identifying barriers, and in learning from a wealth of past experience. We argue that conceptualizing innovation activities, institutions, and actors around the world as a connected socio-technical system provides a new lens that leads to such clarity. Understanding technological innovation in this way will, in turn, profoundly influence the policies that are put in place, the organizations and networks that are built, the technologies that are developed, and ultimately, the collective progress that can be made towards sustainable development.

Three insights from this innovation-system perspective are particularly important in leveraging the potential of technology to meet sustainable development goals: understanding innovation as a complex adaptive system, understanding the socio-technical nature of innovation systems, and understanding how actors shape and are shaped by innovation systems. We argue that actors interested in sustainable development-whether scientists conducting early-stage research, donors selecting particular technologies for funding, or governments promoting technology cooperation at international through local decision-making levels (to name but a few important activities in innovation systems) — will be more effective if they incorporate these insights into their frameworks and practices. In the rest of this Perspective we explore each of these insights in turn, setting forth general conceptual arguments, drawing on the existing theoretical and empirical literature, and illustrating them with a set of common cases summarized in Table 1 . We conclude with proposals for concrete policy action.

\section{Understanding Innovation as a Complex Adaptive System}

The innovation system can be usefully viewed as a complex adaptive system ${ }^{2}$. The connections across the multitude of stages of the innovation process, occurring in multiple sectors and multiple decision-making levels make innovation systems complex and adaptive. As we discuss below, many of the general insights from the study of complex adaptive systems (15-19) apply to innovation systems. Recognition of the complex and adaptive nature of innovation systems is important for understanding how change occurs in such systems and how interventions should be designed and implemented to orient innovation towards the objectives of sustainable development.

\footnotetext{
2 There is a significant history of framing the process of technological change as a complex adaptive system (11-13), wherein technologies evolve through a process of technological recombination. However, we apply the complex adaptive system framework, not only to the process of technological change, but also to the innovation system as a whole, considering technologies in their full social context. Thus, our framing more closely mirrors that of Buckley (1968) who applies the complex adaptive system framework to society at large (14).
} 
In practice, the recognition of innovation as a complex adaptive system is not broadly held, as many actors are only engaged in a specific stage of the innovation system. In order to grapple with the task of orienting innovation systems to meet sustainable development goals, we examine the implications of three complex-adaptive features of innovation systems, namely that: innovation occurs in multiple stages, sectors, and decision-making levels; innovation is non-linear; and innovation systems have tipping points.

\subsection{Innovation Occurs in Multiple Stages, Sectors, and Levels}

Innovation happens in multiple stages that are highly linked, often overlap, and do not necessarily occur in a specific order. By "stage" we refer to a concept used in the academic literature, sometimes under the heading of innovation “mechanisms," "processes," or "functions” (20-22). These notions each capture the variety of activities that occur to make innovation happen. The types of activities that occur in different innovation stages often require different modes of thinking, the engagement of diverse communities of actors (e.g. scientists, local governments, and end-users) (4), and leverage many physical and intangible resources. Further, innovation stages often occur simultaneously across multiple sectors and are coordinated at different levels of organization, from small community niches to multinational governance bodies. There are a number of different ways that these stages can be defined; for convenience, we group innovation stages into categories of activity: invention (e.g., the process leading to the discovery of how to harness a natural phenomenon to remove water pollutants), selection (e.g., the choice of a water treatment technology for a particular setting by an international donor), early adoption (e.g., the use of the selected water treatment technology in a particular rural community), production (e.g., the local manufacturing of the technology, often according to specific standards), adaptation (e.g., efforts by users or inventors to modify the technology to better serve the needs of individual users), widespread use (e.g. the broad adoption of the water treatment technology in a sustained manner over many communities of users), and retirement (e.g., the replacement of the water-treatment technology by a new, more costeffective technology) (23).

Due to the pervasiveness and depth of linkages across stages, sectors, and decision-making levels in innovation systems, intervening in any one part of the innovation system can create "ripple effects" throughout the system. Furthermore, innovation in one technology sector can lead to "spillovers" that enable more rapid improvements and new application areas in other sectors (24). For example, the global positioning system (GPS) was developed for defense applications but has been applied to many other uses, including better targeting of disaster relief. The connections between innovation systems and socialenvironment systems cannot be simply reduced to “externalities” that emerge from technological innovation and use (25). Instead, technologies emerge from social systems and have a reciprocal effect on shaping the social systems from which they emerge (26), as detailed in the discussion of the sociotechnical nature of innovation below. For communities of practice, understanding the overlapping linkages of the stages of the innovation process implies that interventions in the innovation system cannot be designed or evaluated in isolation. Instead, interventions in the innovation system must also consider possible spillover effects (e.g. the impact of local incentives for biofuel development on global food prices (27)).

\subsection{Innovation is Non-Linear}

Innovation does not happen linearly, nor is it a random process. Rather, innovation stages can occur in different chronological sequences throughout a technology's lifecycle. A well-functioning innovation 
system has deep connections and a degree of co-dependence among the stages, making the innovation system non-linear (28). Dynamic technological change nearly always involves a back-and-forth evolution through the stages of innovation, unfolding in a chronological order that rarely traces out a linear development pathway from invention through adaptation and widespread use.

"Success" or "failure" in a particular stage of the innovation system is shaped by other innovation stages. For example, where infrastructure barriers prevent the effective delivery of clean drinking water through centralized systems, ceramic pot filters (CPFs) can be an effective interim solution that enables users to treat water in their homes and thereby reduce the incidence of water-borne diseases. However, some CPF distribution programs face adoption challenges that are related to barriers at the production and selection stages. CPFs can be manufactured with local materials and labor, but a lack of quality control during the production process can inhibit the scaling up and widespread adoption of CPFs. Because the fragile ceramic pots can break during cleaning or transport, adoption is hindered unless an adequate supply chain for replacement parts has been created. Moreover, "split agency” decision-making-i.e. where NGOs or aid agencies select a technology on behalf of the intended users-can stymie adoption of CPFs (see Table 1).

To harness the potential of innovation for sustainable development, activities in different stages should be mutually supportive of each other, and aligned to meet the needs required of sustainable development. For example, efforts to deploy vaccines in resource-poor settings are more likely to be effective if the lack of refrigeration in deployment supply chains is anticipated and accounted for when the technology is being developed.

Development of technologies in protected "niche spaces" can allow for important experimentation and early-stage user interaction to build in necessary feedback (29, 30). For example, engaging users when designing clean biomass cookstoves for Darfur has resulted in fourteen iterations of the stove, leading to more sustained adoption and plans to develop cookstoves suitable for use in Ethiopia (31). Scale-up of a technology for widespread use requires a deep integration of knowledge from a broader group of users and the technology's supporting environment. Effective development agencies should keep close tabs on the wide range of technologies that can serve to address particular goals, as well as on emerging technological developments, types of policy interventions, financing arrangements, and local user preferences.

A systems perspective considers the weakness of feedback loops between the different stages of the innovation process. Strategies to overcome difficulties in the innovation process (e.g., low adoption of a specific technology) require not just a remediation of failures at that particular stage of innovation (e.g., high prices), but also interventions that strengthen the alignment of activities in all stages of the innovation process. In the context of innovation for sustainable development, failure to recognize the weakness of feedback loops is evident in many examples in which unsuitable technologies are selected for targeted development initiatives. We observe that outside actors that control funds and are passionate about specific issues too often inappropriately select technologies for scale-up. These actors often narrow the possible technological solution space without sufficient attention to other stages of the innovation process, including matching technologies to the particular needs of end-users in a given social and environmental context. The SRI and ceramic pot filter cases illustrate that efforts to promote adoption of a technology can be stymied not only by the implementation challenges of increasing adoption of a 
particular technology but also by efforts made in other stages of innovation (such as invention, selection, production or adaptation) (see Table 1).

\subsection{Innovation Systems have Tipping Points}

Like other complex adaptive systems, innovation systems can demonstrate punctuated equilibria whereby thresholds create inconsistent bursts of technological explosion ${ }^{3}$. These "tipping points" in innovation systems are exemplified by past innovations, such as the steam engine, high-yield staple crops, antibiotics, the printing press, and the Internet. Each example featured rapid utilization, rich follow-on innovation, and broad societal change. Tipping points in innovation systems have been referred to as technology "regime changes" or "transitions" (33) and are closely related to "paradigm shifts" in the domain of scientific and philosophical thought (34).

The dynamics of innovation systems are characterized by thresholds that create time lags and other forms of inconsistent technological evolution. In some cases, innovation systems can become path-dependent or “locked-in,” whereby relatively minor changes to initial conditions create persistent effects. Lock-in occurs through reciprocal feedback loops, such as the increasing returns to an initially adopted technology through continuous adaptation and refinement (35). This poses a challenge often faced by (but not exclusive to) new technologies in capital-intensive and infrastructure-dependent sectors. One example is the challenge of replacing fossil fuels with renewable energy, in which scale economies, learning-bydoing in process technologies, the establishment of infrastructure oriented towards incumbents, and the long life of physical capital give economic advantages to incumbent technologies (36).

Across all technologies, lock-in is possible as innovation systems evolve through self-organized microscale processes, arriving at states heavily dictated by existing power dynamics. This dynamic reinforces the positions of those currently in power by biasing innovation towards the preferences of the powerful who could lose from changes to the status quo. In these cases, actors with power bias the institutions governing actor behavior towards preserving the status quo (as we elaborate later in this Perspective). This type of biasing is exemplified in the political lobbying of the fossil fuel and the tobacco industries to preserve fossil fuel subsidies and limit tobacco labeling, respectively. The possibility of lock-in suggests that innovation systems may reach temporary stable equilibria defining dominant, relatively static "technological regimes" (33). Lock-in builds time lags into the innovation system, resisting change until tipping points reorient the system.

In the context of innovation to promote sustainable development, lock-in of underperforming technologies slows the diffusion of new technologies that would improve the well-being of those with the greatest need. The current self-organized system does not sufficiently account for the preferences of all stakeholders (37). The challenge to promote sustainable development is one of designing technologies and policy interventions that navigate technological tipping points and break from path-dependence. Meeting this challenge includes interventions that accelerate and embrace some technological tipping points (e.g. escaping from "poverty traps”), that manage tipping points that have already "tipped” (e.g. increasing access to the technological outcomes of the Green Revolution), and that raise barriers so to avoid other tipping points altogether (e.g. catastrophic climate change). Conceptualizing innovation

\footnotetext{
${ }^{3}$ Mass species extinctions, the possibility of rapid sea level rise after a certain level of climate warming, and rapid economic collapse of the global financial system are examples of observed and predicted tipping points of complex adaptive systems (32).
} 
system change as one of navigating tipping points requires emphasizing the potential for relatively small actions that affect conditions at key leverage points to have large impacts. The SDGs reflect the inadequacy of current systems to deliver necessary innovation, which is due, in part, to path dependency and associated power dynamics.

\section{Understanding the Socio-Technical Nature of Innovation Systems}

Understanding innovation systems requires both social and technical insights. Research in the sociology of knowledge and in science and technology studies demonstrates the complex and interwoven relationship between technology and society (38). While these disciplines approach the "co-production" of knowledge, technology, and society from a constructivist lens, understanding the mutual influence of social and technical systems should also inform the ways in which actors in the innovation system can most effectively design approaches to harness innovation for sustainable development. To explore the implications of this insight, in this section we elaborate on how innovation systems are influenced by their socio-technical characteristics (STCs); show how analyzing the STCs of a particular innovation problem can serve to diagnose bottlenecks in innovation systems; and propose that awareness of STCs can facilitate learning across technologies, sectors and contexts. Together, these implications form the basis for an analytic approach to assessing innovation based on STCs that can increase the likelihood of ex-ante identification of problems and can help discover overlooked social dimensions within an innovation system. This approach can also facilitate learning by advancing understanding of and capacities for leveraging the experimentation taking place across various sustainable development arenas (e.g. health, energy, agriculture, water and manufacturing). Too often, potential lessons to be learned from this experimentation remain siloed in individual practitioner and academic communities despite their potential to be usefully compared in terms of their STCs.

\subsection{Technology and Society are Co-Produced}

Societies are both users and producers of technology. This mutually constitutive relationship between society and technology is essential to understand in advancing the contributions of technology for sustainable development. The relationship between knowledge, technology, and society is elaborated as "co-production" in the literature of science and technology studies (39). Co-production is a theoretical and analytic concept that facilitates the study of how technology and society influence each other in ways that cannot be easily untangled $(38,40,41)$. Co-production draws attention to the dynamics operating at the nexus of technology and society; in doing so, it recognizes that the design of technologies, as well as the innovation processes from which they emerge, reflect-and reproduce-the cultural preferences and the economic and political resources of their inventors, selectors, and users. Co-production sheds light (for example) on the ways that technological projects and innovation agendas reflect broader social, political, and even moral commitments of the societies that undertake them (e.g., why particular actors choose to promote particular technologies), and the reasons diverse societies privilege different outcomes or forms of evidence relating to risk and benefit over others. For example, in a context where investment in high-technology was a state-building strategy, the policies and regulations promoting nuclear power in South Korea reflected the country's leader's focus on economic development, while in the United States the politics of nuclear power focused instead on whether risks to public health and safety and of proliferation could be adequately contained (42). While nuclear energy was the technological focus of these distinct approaches, these approaches reflect several differences in political and normative 
relationships, in the ways risks are imagined and regulation is undertaken, and in the manner in which technological undertakings figure in shared political imaginations of progress and public benefit. Thus, social, legal and political institutions simultaneously shape and are shaped by scientific and technological developments (38).

We take our cue from the rich social-theoretic construct of co-production to frame the importance of understanding the socio-technical nature of innovation. We focus here on how actors with agency can better understand and intervene in shaping innovation systems. To make innovation work for sustainable development, practitioners attempting to address a particular goal must avoid considering technologies too narrowly, attending instead to the broader socio-technical context of their work. For example, in the context of low-carbon technology transfer, it has been argued that a holistic understanding of economic, political, institutional and legal factors is needed (43). The socio-technical context includes actors (e.g., inventors, users, firm producers and adopters) (4, 28), institutions (e.g., norms, laws, culture) (3), and physical and environmental infrastructure (e.g., roads, ports, electricity grids, irrigation systems, and supply chains for various services) $(36,44)$. Together, this set of contextual considerations and the characteristics of technologies themselves can be thought of as the STCs that characterize an innovation system at a particular point in time.

STCs provide fruitful analytic traction to understand and diagnose possible bottlenecks that may emerge when attempting to advance sustainable development in particular innovation system contexts. A focus on developing insights inductively through cases with shared STCs, rather than insights drawn strictly from within sectors (e.g. energy) or for certain actor groups (e.g. donors), has great potential for developing deeper knowledge into the generalizable challenges of leveraging innovation for sustainable development. However, the broad diversity of STCs across locations and technologies also suggests a needed degree of humility. Applying the experiences and policies in one technology or social context without careful consideration of STCs may lead to failure in another context. For example, because cooking practices in Ethiopia are different from those in South Sudan, promoting the adoption of the same cookstove technology in both places may hinder its widespread use, an insight which led an NGO to work on adapting the Berkeley Darfur Stove for its use in Ethiopia (see Table 1).

\subsection{Socio-technical Characteristics Diagnose Barriers to Innovation}

STCs can be used analytically to develop inductive hypotheses about general conditions under which innovation systems work to meet local needs ${ }^{4}$. Because STCs are a guiding concept for inductive investigation, no comprehensive list of relevant STCs exists. However, their usefulness emerges from the ability of scholars and practitioners to incorporate new observations from a variety of different geographical, social, and technological contexts (including those outside of advanced industrial economies). In some cases, investigating unfamiliar cases with similar STCs may lead actors embedded in the practice surrounding one technology to question their own assumptions about the suitability or value of specific actions to promote a technology or objective. Here, we present four STCs to demonstrate the utility of an STC-focused approach to diagnosing innovation barriers across a range of sectors, building on empirical evidence and academic theory in a variety of disciplines ${ }^{5}$. The four STCs discussed below

4 Scholars in the technology innovation systems literature have proposed studying seven functions of innovation systems to identify weaknesses that policy makers need to strengthen. This approach has relied almost exclusively on experiences from industrialized countries (45) and is complementary to the approach suggested here.

${ }^{5}$ A more extensive list of STCs can be found in Anadon, et al., 2014 (46). 
are the presence of network externalities, mundaneness, the existence of standards and certification, and modularity. These STCs demonstrate the importance of understanding the socio-technical nature of innovation: each STC demonstrates the mutual influence of social and technical systems.

\subsubsection{STC: Presence of network externalities}

Network externalities exist when the adoption of a particular technology by some increases the benefits from using the technology for others. Therefore, users of technologies with network externalities benefit more from their use of the technology as the total number of users increases. Network externalities are particularly prevalent in innovation systems where social learning and local peer effects are important for increasing adoption or for effectively utilizing a technology. One example is residential solar photovoltaic (PV) adoption in California, which saw increasing technology adoption as peer effects grew stronger and residential consumers learned about the benefits of a technology through local networks (47). The role of network externalities in accelerating technology adoption suggests the importance of strategic information transmission and marketing to complement peer-to-peer information sharing.

Network externalities create "increasing returns" to technology adoption, which suggests that technologies may be locked-in when network effects are strong and social learning is an important factor in adoption and effective utilization (35). However, in the context of sustainable development, innovation systems to promote locally desirable technologies that could benefit from social learning to reinforce adoption and utilization have sometimes struggled to develop self-sustaining networks of peers (48). This dynamic is a major challenge for the EcoTEDA industrial symbiosis program in Tianjin, China, which relies on the exchange of resources between firms in the network to reduce local impacts of manufacturing. EcoTEDA has struggled to bring in enough users to keep their industrial symbiosis program viable after the end of their funding grant from SWITCH-ASIA (UNIDO) (see Table 1).

\subsubsection{STC: Mundaneness of the technology}

A mundane technology is a technology that does not hold the attention of key actors, especially actors who play important roles in technology invention and selection. Fundamentally, mundaneness is determined by social expectations and perceptions including whether a technology is considered novel or even whether it fits into pre-existing frameworks of what characteristics a technology to meet a particular need should have. Empirically, mundane technologies tend to draw on simpler scientific principles than technologies that gain attention of powerful actors. Expectations and perceptions shaping mundaneness play a central role in influencing the decisions of consumers and researchers, mobilizing resources in the innovation system, and guiding priorities and policies (49).

The role of mundaneness is exemplified by the development of the system of rice intensification (SRI) in Madagascar (see Table 1). In the case of SRI, established research centers working on high-yielding and drought-resistant seed varieties were initially skeptical of the benefits of a more mundane practice-based technology for improving rice yields. The mundaneness STC cautions practitioners to be self-aware of institutional and social-perception-based influences that may unduly restrict the solution set of interventions they consider, as well as the social needs they choose to address. Otherwise, interventions risk providing solutions only for the needs that can be met with fashionable technological solutions instead of solutions that may be more mundane but also more effective. 


\subsubsection{STC: Existence of standards and certification}

Standards and certification facilitate learning and cost reductions by increasing confidence that particular technological solutions will be supported by a broader system of compatible complementary technologies and institutions (20, 30, 50, 51). Standards and certification may emerge from the bottom-up as a necessity of cost-effective private practice or may be imposed top-down to coordinate activity and even to direct technological change. Like network externalities, standards and certification may also contribute to technology lock-in, as the relative costs of alternatives that do not rely on existing infrastructure and institutions rises (36).

The Berkeley Darfur Stove case discusses the role that the lack of standards played in the perceived lack of adoption of many previous cookstove projects. To address this issue, the international cookstove research community has developed international testing standards, including agreed upon methods to test stove efficiency and emissions. These standards act as a tool by which stoves are evaluated and are an important factor in driving investment (e.g. through carbon markets and private grants) $(52,53)$ (see Table 1).

\subsubsection{STC: Level of modularity}

A modular product or process is comprised of design elements that are easily disaggregated and organized according to a formal architecture or plan (54). Modularity may be a direct consequence of technological design, but it may also be more directly socially constructed (e.g. in software design or in technologies with intellectual property restrictions covering individual components of systems). A modular technology can therefore change via innovation in a subset of its components that are reintegrated into the whole without requiring complete redesign. More modular technologies have lower barriers to adaptation because the separability of components allows actors to improve an individual component without the architectural knowledge of the entire technology, which may be difficult to acquire (55).

Modularity may facilitate wider adoption, sometimes at the expense of imitation from other entities (56) who can more readily copy and evaluate modular components without integrating them into a technological system first. After some success in supporting the adoption of the Berkeley Darfur Cookstove (BDS) in Darfur, Sudan (which required fourteen design iterations), the Berkeley cookstove team sought to expand deployment of cookstoves to Ethiopia. Due to differences in cooking practices, they identified that adoption of the BDS in this new context would require adaptation. This adaptation was facilitated by the modularity of the technology: while a common shell is mass produced in India, local adaptation is possible through the use of different pot supports (52). Not only are the costs to adaptation lower with increasing modularity, but entrepreneurial technology managers may be able to expand the contexts in which their technology is suitable, and therefore serve a wider array of human needs by adapting modular technologies. The extent to which more or less modularity is needed for adaptation also depends on the capabilities of adapters.

\subsection{Socio-technical Characteristics Facilitate Learning in Innovation Systems}

Practitioners with a stake in advancing sustainable development usually have a limited set of experiences from which to develop evidence-based policy and action strategies. Too often, practitioners struggling to

make innovation work for a particular local need fail to benefit from the experience of others, often 
because they are siloed in individual sectors or local contexts. Effective learning therefore requires bringing to bear evidence from a broader set of past experiences. An STC-based approach to developing insights from past experience can facilitate learning across sectoral, technological, and geographic divides. The concept of STCs can facilitate the identification of whether an intervention or institution that worked for a particular technology and context could be suitable for the same technology in a different context, a different technology in the same context, or even a different technology and context.

Most learning from previous experience tends to happen within sectors as practitioners and researchers interact with others working on closely related areas and do not draw on experience only known to experts in other sectors (57). More cross-sectoral learning is needed to improve the innovation system in meeting the goals of sustainable development in a resource-effective way. We have found that the specific STCs of a technology and its context are often more similar across different sectors than within the same sector. An example is the many similarities between the STCs creating bottlenecks for the adoption of cookstoves and the adoption of ceramic pot filters. In contrast, very different STCs shape innovation bottlenecks for technologies in the energy sector, such as cookstoves and coal-power plants with carbon capture and storage.

An example of potential learning across sectors from an STC perspective is the experience from efforts to make the price of artemisinin-based combination therapy (ACT) for malaria treatment affordable for rural populations in sub-Saharan Africa and Southeast Asia (see Table 1). A group of global health funding organizations including the Global Fund to Fight AIDS, Tuberculosis and Malaria (GFATM) and UNITAID created a global subsidy called the Affordable Medicines Facility-malaria (AFMm) which reduced the price of ACTs to end-users. Manufacturers received the global subsidy directly, and then shipped reduced-price drugs to countries. They were then supplied to both public and private sector distribution channels in order to get the technology into informal village level supply chains at a cost competitive with less desirable treatment options. Important STCs in this case include that end-users were individuals with limited financial and information resources (e.g., at the clinic and patient levels), price was high relative to inferior alternatives, and the technology required lengthy transnational supply chains to get from the manufacturer to the end-user. Drought-resistant seed varieties have similar STCs to those in the ACT case-small-scale end-users (e.g. small-holder farmers), high relative prices, and lengthy transnational supply chains. These shared STCs suggest that a similar global subsidy could be useful for making drought resistant seed varieties more affordable to farmers in developing countries.

\section{Understanding How Actors Shape and are Shaped by Innovation Systems}

Innovation systems are comprised of technologies, actors who affect and are affected by technological change, and the institutions that govern their actions. Examples of such actors include inventors, investors, firms, intermediaries, and technology users. Actors in an innovation system may be separated by many years in time, by thousands of miles in space, and by vast differences in power and interests. Their decisions are governed by institutions operating at community, country, and global levels. Examples of institutions include national laws and regulations, international treaties, human rights norms, and sustainable development goals.

Existing innovation systems are often poorly suited to meet sustainable development objectives. Reorienting current systems to address these shortcomings is therefore essential but difficult for at least two reasons. First, innovation systems comprise activities of a multitude of actors working at local, national 
and transnational levels within and across multiple stages of the innovation process. This makes alignment of activities challenging in the absence of a centralized authority (such as a single powerful state or firm). Second, existing institutions, such as market incentives and national policy frameworks, shape and constrain the behaviors of actors in innovation systems but are often not aligned towards sustainable development objectives. However, actors possess agency and can mobilize many types of power to change existing institutions in order to better meet sustainable development goals.

\subsection{Innovation Systems Involve Many Actors Operating at Different Stages and Levels}

As highlighted in our discussion of innovation as a complex adaptive system, innovation systems are complex because actors in the innovation system operate across different innovation stages and decisionmaking levels through interdependent activities. The interdependencies of actors in the innovation system may be explicit, such as through technology commercialization licensing agreements that involve a formal contract transferring intellectual property from one actor to another (58). Alternatively, linkages connecting actors may be implicit, such as the underappreciated dependence of new product development at many computer hardware technology and pharmaceutical firms on government-funded R\&D conducted decades earlier $(59,60)$. Given the complexity of interdependent actors across different innovation stages and levels, aligning the activities of these diverse actors towards sustainable development objectives is a challenge.

Across the stages of innovation, actors are involved in inventing, selecting, manufacturing, adapting, adopting, and retiring a technology. Nearly always, individual actors engage in only a subset of these stages. In the ACT case, the Chinese government established research priorities, public sector scientists and private firms invented the first ACT, the World Health Organization and several non-governmental organizations (NGOs) and academics selected and promoted the use of ACTs above older alternatives, the GFATM and UNITAID were involved in making the technology affordable in malaria-endemic countries, drug retailers in sub-Saharan Africa and Southeast Asia supplied the drugs, healthcare workers prescribed ACTs, and patients themselves ultimately decided whether to purchase and take them (see Table 1). In this case, as well as many others, the sheer number of actors made it difficult to align their activities towards a shared sustainable development objective.

In some cases, actors may engage in more than one innovation stage, such as when end-users of rice farming technologies engaged in invention that led to the creation of the system of rice intensification (SRI). However, even when actors engage in multiple innovation stages, they rarely engage in all stages, and the problem of aligning actor behavior towards sustainable development persists. While the end-user inventors of SRI could use their technology locally in Madagascar, success in scaling up the technology required the activities of many other actors to promote the technology in different places and decisionmaking levels (see Table 1).

Not only is cross-stage alignment difficult to achieve, but aligning actors working at different decisionmaking levels of the innovation system is also challenging. The problem of misalignment is particularly relevant when needs that vary at the local level are not fully incorporated into decision-making at national, transnational, or global levels. In efforts over the past few decades to promote the development and adoption of cleaner and more efficient cookstoves, inventors and selectors of technologies were often not fully engaged in local contexts and they lacked an adequate understanding of the needs of end-users. This led to significant roadblocks in achieving widespread adoption and limited the impact of cookstove 
technology because many stove designs promoted by transnational actors proved unsuitable for the preparation of local dishes(61).

Aligning actors within innovation systems with sustainable development objectives is difficult because actors operating across different stages and levels vary in their interests and incentives. In some cases, actors are strongly driven by the organizing principle of market forces. In other cases, the dominant organizing principle may be that of a centralized authority that creates rules that govern the behavior of actors across all (or many) stages and levels of the innovation process, such as a single state or private firm. Frequently, markets and states together coordinate actors in innovation systems across scales and levels. However, these dominant forces are not necessarily oriented towards sustainable development. A national government usually has little motivation to take into account the needs of citizens beyond its borders, a profit-maximizing firm has insufficient incentive to invent technologies for people who cannot afford its products, and consumers lack the impetus to consider how their decisions impact other communities distant in time or space. In the ACT case, patients had little incentive to consider the probability of future drug resistance when deciding how to treat their own malaria cases today (see Table 1).

\subsection{Institutions Shape Actor Behavior, but are Not Necessarily Aligned towards Sustainable Development}

Institutions include the set of formal and informal rules, norms, decision-making procedures, beliefs, incentives and expectations that guide the interactions and behavior of actors in the innovation system (62-65). Institutions govern actors across all stages of the innovation process, and often, there are distinct

sets of rules and norms governing invention, selection, production, adaptation, adoption and retirement. In addition, institutions operate across multiple levels of the innovation system, including customs that extend no further than a particular village, regional or national laws, and codified international norms, such as those embodied in international conventions (45).

The institutions created by states and firms often fail to align actor behaviors towards sustainable development. For example, industrial symbiosis is a set of technologies to reduce the impacts of manufacturing by linking wastes and byproducts in one firm to the input needs in another. Yet private incentives for firms to engage in industrial symbiosis in Tianjin, China were hampered by a lack of financial and regulatory incentives to reduce waste and emissions (see Table 1). Drip irrigation is a technology for irrigating plants that reduces water requirements and improves the water use efficiency of many crops. In India, where this technology has been selected for adoption, institutions shaping market forces initially set prices for the technology higher than most farmers could afford and limited adoption prevented farmers from learning about the technology's long-term benefits. These barriers, in turn, provided few incentives for private companies to market their technology to small farmers (see Table 1).

\subsection{Actors Can Change Institutions to Re-orient Innovation Systems towards Sustainable Development}

As illustrated in the ACT, industrial symbiosis, drip irrigation cases cited above, the pre-existing set of rules or norms that shape innovation systems are not necessarily aligned towards sustainable development. While institutions constrain actor behavior in the short term, institutions are not immutable. The incentives, capabilities, and needs of actors that comprise innovation systems co-evolve with 
governing institutions (66-68). So although the capacity and power of actors depend on institutions, institutions themselves are shaped by actors and can change in both incremental and radical ways (63).

Innovation systems are often path-dependent and perpetuate the status quo. Existing institutions frequently protect sub-optimal incumbent technologies, sustain power imbalances, or otherwise maintain incentives for technological innovation that does not advance sustainable development. The inherent "stickiness" of institutions makes changing innovation systems a daunting task that requires leveraging multiple types of power. These include: the normative power to challenge the moral acceptability of existing institutions; the convening power to bring actors together to establish new goals, priorities, and agendas; the legal power to negotiate and revise norms, binding rules, and/or standards; the power of information and expertise to identify alternatives and assess their feasibility; and the financial power to create incentives for other actors, implement costly new policies, or reduce the risks or costs of doing so $(46,69)$.

Actors, including international organizations, national non-profit and advocacy groups, private firms and government regulatory bodies, can change the innovation system by challenging the rules and norms that govern the behavior of other actors (70-72). Here, we provide three examples of how actors have induced institutional change in ways that promote sustainable development. In the drip irrigation case, government bureaucrats in the Indian state of Andhra Pradesh saw the potential for the technology to increase farmer yields and conserve water in the drought-affected state but noted that most farmers could not afford the technology. To overcome this barrier, the state government designed a subsidy policy that incentivized private sector companies to take responsibility for marketing and extension of drip irrigation technology, while reducing costs to farmers. The new rules created an incentive structure that led to widespread use of drip irrigation technology. In this example, the government relied on its legal power to change the rules shaping the behavior of private firms and its financial power to implement the new rules (i.e. the subsidy). In contrast, in the case of SRI, a loose network of activists, lacking both legal and financial power, turned to their information and convening power to build a coalition of support for SRI. In the ACT case, NGOs and academics mobilized their normative power to mount a public advocacy campaign to challenge the then-prevailing norm that donors should not subsidize relatively expensive medicines for poor populations because of concerns regarding the long-term sustainability of those payments (see Table 1).

In sum, sustainable development is not yet a strong enough organizing principle in most innovation systems to align actor behavior to systematically take into account the interests of marginalized populations or future generations. Re-aligning innovation systems towards sustainable development will require changing existing institutions across all stages of the innovation process, from invention through widespread use and retirement, and at multiple decision-making levels, from local to global. The evidence shows that such changes can indeed be brought about by committed actors who strategically mobilize the multiple types of power available to them.

\section{Conclusion}

Technological innovation has played a central role in achieving important societal objectives, such as economic growth or improved human well-being. But innovation systems, driven primarily by markets and the most highly-resourced states, are characterized by pervasive power imbalances, such that the needs of marginalized populations and future generations are not adequately met. How can these power imbalances be addressed? Re-orienting innovation systems towards sustainable development will require 
transforming many of the deeply embedded institutions that limit innovation systems from delivering on their potential. We offer three concrete examples of the types of actions that would begin to do so.

First, more global effort is needed to invest in the invention of suitable and affordable technologies that can contribute to sustainable development. The problems of neglected diseases, orphan crops, and underinvestment in clean energy $\mathrm{R} \& \mathrm{D}$, illustrate that market incentives alone are inadequate to drive invention and need to be supplemented by policy change and strategic investment. Such investment can take many forms, such as public funding for R\&D or private funding incentivized by targeted policies. The creation of a carbon price through regional, national, and sub-national carbon markets is an important example of creating new rules to change the incentives facing the private sector. Putting a price on carbon increases the financial incentive for firms to invent alternative, lower-carbon energy technologies to mitigate the present and future impacts of climate change. Without concerted efforts to change the rules and incentives governing invention, we will continue to face a shortage of technologies needed for sustainable development.

Second, measures are needed to engage marginalized populations more systematically throughout all stages of the innovation process. Since marginalized and future populations often lack the power needed to influence the innovation system, problems arise such as third parties (e.g. donors) selecting technologies poorly suited for the context in which they are to be used. There is also untapped potential for end-users to adapt technologies for use in new contexts (30). Actors who do possess certain forms of power can and should identify ways to improve the involvement of marginalized populations in innovation (73). These engagement strategies need not be costly. For example, actors with convening power and normative authority, such as large NGOs and United Nations agencies, can directly engage marginalized populations when negotiating norms and establishing priorities rather than speaking on behalf of directly-affected populations. Capacity-building among less-powerful populations to organize and represent their interests in such forums is also needed. One example is the shift in the multilateral climate regime to policies that more deeply engage developing countries in climate change innovation. Previously, international institutions primarily focused on technology transfer-exporting technology from a more advanced country to developing countries. However, newer forms of cooperation focus more on engaging developing country actors in the process of technology invention and selection by reducing information asymmetries, decreasing social distance between actors with expertise and skills, and fostering new collaborative arrangements (74).

Third, measures are needed to regularize learning across spheres of practice to improve understanding of how to re-orient innovation systems towards sustainable development. Understanding is a necessary precondition for the development of carefully targeted interventions to counteract the power imbalances that inhibit realizing the full potential of innovation. Actors with convening power should facilitate sharing across disparate communities of practice. To take just one example, policy experiments to promote R\&D for new medicines over the past decades can inform efforts to reform approaches to innovation in agriculture. Many potential cross-sectoral lessons are available (57), but drawing appropriate conclusions requires a degree of analytical rigor, as suggested by our presentation of generalized findings based on STCs.

Altering the norms, rules, and practices governing innovation may appear politically or practically impossible in the short-run, particularly when the powerful do not find reform to be in their interests. Yet without institutional change, certain populations will remain excluded from the benefits of innovation, and the interests of present generations will continue to unfairly outweigh those of the future. Making 
technological innovation work for sustainable development will require making fundamental changes to the rules of the game. 


\section{Acknowledgements}

The empirical foundation for this paper was developed over the course a multi-year research Project on Innovation and Access to Technologies for Sustainable Development based at the Harvard Kennedy School (HKS). It was supported by the Sustainability Science Program at HKS and Italy's Ministry for Environment, Land and Sea, with contributions from the Science, Technology and Public Policy Program of the HKS Belfer Center for Science and International Affairs. We thank the many researchers who contributed case-studies and background papers to the project and provided helpful feedback: Ahmed Abdel Latif, Dwayne Appleby, Kathleen Araujo, Françoise Bichai, Kayje Booker, Hyundo Choi, Sharon Davis, Brian Dillon, Kristian Dubrawski, Stephen Elliott, Ram Fishman, Lonia Friedlander, Arani Kajenthira Grindle, Ben Hurlbut, Christina Ingersoll, Erin Kempster, Daniele Lantagne, Laura Pereira, Polina Ponce de Leon, John-Arne Röttingen, Daniel Shemie, Lucilla Spini, Jennie Stephens, Vanessa Timmer, Livio Valenti, Lee Vinsel, Mark Williams, Paul Wilson, and Alyssa Yamamoto. We are grateful to the very useful feedback received from participants at a one-day workshop sponsored by the Weatherhead Center for International Affairs at Harvard University in April 2014. All errors are the sole responsibility of the authors. 


\section{References}

1. UN (2015) Transforming Our World: The 2030 Agenda for Sustainable Development (United Nations General Assembly) Available at:

http://www.un.org/ga/search/view_doc.asp?symbol=A/RES/70/1\&Lang=E.

2. Brooks H (1980) Technology, evolution, and purpose. Daedalus 109(1):65-81.

3. Lundvall B-Å (2010) National Systems of Innovation : Toward a Theory of Innovation and Interactive Learning (Anthem Press, London; New York).

4. Nelson R (1993) National Innovation Systems: A Comparative Analysis (Oxford University Press, New York).

5. Freeman C (1987) Technology, Policy, and Economic Performance: Lessons from Japan (Pinter Publishers, London; New York).

6. Pedrique B, et al. (2013) The drug and vaccine landscape for neglected diseases (2000-11): a systematic assessment. Lancet Glob Health 1(6):e371-e379.

7. Schmookler J (1962) Economic sources of inventive activity. J Econ Hist 22(1):1-20.

8. Mowery D, Rosenberg N (1979) The influence of market demand upon innovation: a critical review of some recent empirical studies. Res Policy 8(2):102-153.

9. Solow R (2012) Sustainability: an economist's perspective. Economics of the Environment, ed Stavins R 6th Ed.

10. Garb Y, Friedlander L (2014) From transfer to translation: using systemic understandings of technology to understand drip irrigation uptake. Agric Syst 128:13-24.

11. Fleming L, Sorenson O (2001) Technology as a complex adaptive system: evidence from patent data. Res Policy 30(7):1019-1039.

12. Abernathy WJ, Utterback JM (1978) Patterns of industrial innovation. Technol Rev 80(7):40-end.

13. Schumpeter JA (1942) Capitalism, Socialism, and Democracy (Harper and Brothers, New York).

14. Buckley W (1968) Society as a complex adaptive system. Modern Systems Research for the Behavioral Scientist, ed Buckley W (Aldine Publishing Company, Chicago, IL), pp 490-513.

15. Arthur WB (1995) Complexity in economic and financial markets. Complexity 1(1):20-25.

16. Holland JH (1992) Complex adaptive systems. Daedalus 121(1):17-30.

17. The National Academies Keck Futures Initiatives, National Academies (2009) Complex Systems: Task Group Summaries (National Academies Press, Washington, D.C.) Available at: http://www.nap.edu/catalog/12622 [Accessed December 17, 2015].

18. Mitchell M (2011) Complexity: A Guided Tour (Oxford Univ. Press, Oxford). 1. paperback ed. 
19. Levin S, et al. (2013) Social-ecological systems as complex adaptive systems: modeling and policy implications. Environ Dev Econ 18(02):111-132.

20. Hekkert MP, Suurs RAA, Negro SO, Kuhlmann S, Smits REHM (2007) Functions of innovation systems: A new approach for analysing technological change. Technol Forecast Soc Change 74(4):413-432.

21. Pavitt K (2006) Innovation processes. The Oxford Handbook on Innovation, eds Fagerberg J, Mowery D (Oxford University Press, Oxford).

22. Hughes T (2012) The evolution of large technological systems. The Social Construction of Technological Systems: New Directions in the Sociology and History of Technology, eds Bijker WE, Hughes T, Pinch TJ (MIT Press, Cambridge, Mass), pp 51-82. Anniversary ed.

23. Chan G, et al. (2015) Crossing the divide in studies of innovation: A unifying framework for analyzing multilevel innovation systems. Prog.

24. Griliches Z (1992) The search for R\&D spillovers. Scand J Econ 94:S29-47.

25. Breschi S (2001) Knowledge spillovers and local innovation systems: a critical survey. Ind Corp Change 10(4):975-1005.

26. Bijker WE, Hughes TP, Pinch TJ eds. (2012) The Social Construction of Technological Systems: New Directions in the Sociology and History of Technology (MIT Press, Cambridge, Mass). Anniversary ed.

27. Zilberman D, Hochman G, Rajagopal D, Sexton S, Timilsina G (2013) The impact of biofuels on commodity food prices: assessment of findings. Am J Agric Econ 95(2):275-281.

28. Kline SJ, Rosenberg N (1986) An overview of innovation. The Positive Sum Strategy: Harnessing Technology for Economic Growth, eds Landau R, Rosenberg N (National Academy Press, Washington, D.C), p 290.

29. Kemp R, Schot J, Hoogma R (1998) Regime shifts to sustainability through processes of niche formation: the approach of strategic niche management. Technol Anal Strateg Manag 10(2):175-198.

30. Lebel L, Lorek S (2008) Enabling sustainable production-consumption systems. Annu Rev Environ Resour 33:241-275.

31. Booker KM, Gadgil AJ, Winickoff DE (2012) Engineering for the global poor: the role of intellectual property. Sci Public Policy 39(6):775-786.

32. Advisory Committee for Environmental Research and (2009) Transitions and Tipping Points in Complex Environmental Systems (NSF) Available at: http://www.nsf.gov/geo/ere/ereweb/acere/nsf6895_ere_report_090809.pdf.

33. Geels FW (2002) Technological transitions as evolutionary reconfiguration processes: a multi-level perspective and a case-study. Res Policy 31(8-9):1257-1274.

34. Kuhn TS (1962) The Structure of Scientific Revolutions (The University of Chicago Press, Chicago). 
35. Arthur WB (1989) Competing technologies, increasing returns, and lock-in by historical events. Econ $J$ 99(394):116-131.

36. Unruh GC (2000) Understanding carbon lock-in. Energy Policy 28(12):817-830.

37. Ostrom E (1999) Revisiting the commons: local lessons, global challenges. Science 284(5412):278282.

38. Jasanoff S (2004) Ordering knowledge, ordering society. States of Knowledge: The Co-Production of Science and Social Order (Routledge, London), pp 13-45.

39. Thompson C (2010) Co-producing CITES and the African elephant. States of Knowledge: The CoProduction of Science and Social Order, ed Jasanoff S (Routledge, London), pp 87-108.

40. Murmann JP (2003) Knowledge and Competitive Advantage: The Coevolution of Firms, Technology, and National Institutions (Cambridge University Press, Cambridge; New York).

41. Trist E (1981) The evolution of socio-technical systems as a conceptual framework and as an action research program. Perspectives on Organization Design \& Behavior, eds Van de Ven A, Joyce W (John Wiley \& Sons, New York), pp 19-75.

42. Jasanoff S, Kim S-H (2009) Containing the atom: Sociotechnical imaginaries and nuclear power in the United States and South Korea. Minerva 47(2):119-146.

43. Rai V, Funkhouser E (2015) Emerging insights on the dynamic drivers of international low-carbon technology transfer. Renew Sustain Energy Rev 49:350-364.

44. Grübler A, Nakićenović N, Victor DG (1999) Dynamics of energy technologies and global change. Energy Policy 27(5):247-280.

45. Markard J, Truffer B (2008) Technological innovation systems and the multi-level perspective: towards an integrated framework. Res Policy 37(4):596-615.

46. Anadón LD, et al. (2014) Innovation and Access to Technologies for Sustainable Development: Diagnosing Weaknesses and Identifying Interventions in the Transnational Arena (Sustainability Science Program Working Paper No. 2014-01, Kennedy School of Government, Harvard University, Cambridge, MA).

47. Bollinger B, Gillingham K (2012) Peer effects in the diffusion of solar photovoltaic panels. Mark Sci 31(6):900-912.

48. Kremer M, Miguel E (2007) The illusion of sustainability. Q J Econ 122(3):1007-1065.

49. Borup M, Brown N, Konrad K, Van Lente H (2006) The sociology of expectations in science and technology. Technol Anal Strateg Manag 18(3-4):285-298.

50. Bergek A, Jacobsson S, Sandén BA (2008) "Legitimation” and “development of positive externalities": two key processes in the formation phase of technological innovation systems. Technol Anal Strateg Manag 20(5):575-592.

51. Garud R, Karnøe P (2003) Bricolage versus breakthrough: distributed and embedded agency in technology entrepreneurship. Res Policy 32(2):277-300. 
52. Booker K (2016) Berkeley Darfur Cookstove: Case Study (Sustainability Science Program, Harvard University, Cambridge, MA).

53. ISO (2012) ISO/IWA 11:2012(en), Guidelines for Evaluating Cookstove Performance (International Organization for Standardization) Available at: https://www.iso.org/obp/ui/\#iso:std:iso:iwa:11:ed1:v1:en [Accessed December 17, 2015].

54. Baldwin CY, Clark KB (2006) Modularity in the design of complex engineering systems. Complex Engineered Systems, eds Braha D, Minai AA, Bar-Yam Y (Springer Berlin Heidelberg, Berlin, Heidelberg), pp 175-205.

55. Henderson RM, Clark KB (1990) Architectural innovation: the reconfiguration of existing product technologies and the failure of established firms. Adm Sci Q:9-30.

56. Ethiraj SK, Levinthal D, Roy RR (2008) The dual role of modularity: innovation and imitation. Manag Sci 54(5):939-955.

57. Harley A, et al. (2014) Innovation and Access to Technologies for Sustainable Development: A Global Systems Perspective (Sustainability Science Program Working Paper Working Paper No. 2014-02, Kennedy School of Government, Harvard University, Cambridge, MA).

58. Arora A, Fosfuri A, Gambardella A (2004) Markets for Technology: The Economics of Innovation and Corporate Strategy (MIT, Cambridge, Mass.; London).

59. Mazzucato M (2014) The Entrepreneurial State: Debunking Public vs. Private Sector Myths (Anthem Press, London; New York). Revised edition.

60. Sampat BN, Lichtenberg FR (2011) What are the respective roles of the public and private sectors in pharmaceutical innovation? Health Aff (Millwood) 30(2):332-339.

61. World Bank (2011) Household Cookstoves, Environment, Health, and Climate Change: A New Look at an Old Problem (Washington, D.C.) Available at:

http://documents.worldbank.org/curated/en/2010/03/14600224/household-cook-stoves-environmenthealth-climate-change-new-look-old-problem [Accessed December 10, 2015].

62. Krasner SD (1982) Structural causes and regime consequences: regimes as intervening variables. Int Organ 36(2):185-205.

63. North DC (1990) Institutions, Institutional Change and Economic Performance (Cambridge University Press).

64. March JG, Olsen JP (2004) The Logic of Appropriateness (Arena).

65. Johnson B (2010) Institutional learning. National Systems of Innovation: Toward a Theory of Innovation and Interactive Learning, ed Lundvall B (Anthem Press, London; New York), pp 23-46.

66. Carlsson B, Stankiewicz R (1991) On the nature, function and composition of technological systems. J Evol Econ 1(2):93-118.

67. Edquist C (2005) Systems of innovation: perspectives and challenges. Oxford Handbook of Innovation (Oxford University Press, Oxford), pp 181-208. 
68. Malerba F (2002) Sectoral systems of innovation and production. Res Policy 31(2):247-264.

69. Moon S, et al. (2015) The global innovation system: a typology of transnational functions for enhancing the benefits of technology for sustainable development. Prog.

70. Barnett MN, Duvall R eds. (2005) Power in Global Governance (Cambridge University Press, Cambridge, UK ; New York).

71. Hood C, Margetts H (2007) The Tools of Government in the Digital Age (Palgrave Macmillan, Basingstoke). New ed.

72. Howlett M (2011) Designing Public Policies: Principles and Instruments (Routledge, Abingdon, Oxon; New York).

73. van Kerkhoff L, Lebel L (2006) Linking knowledge and action for sustainable development. Annu Rev Env Resour 31:445-477.

74. Ockwell D, Sagar A, de Coninck H (2015) Collaborative research and development (R\&D) for climate technology transfer and uptake in developing countries: towards a needs driven approach. Clim Change 131(3):401-415.

75. Moon S (2009) Medicines as global public goods: the governance of technological innovation in the new era of global health. Glob Health Gov II(2). Available at:

http://www.ghgj.org/Moon_Medicines\%20as\%20Global\%20Public\%20Goods.pdf.

76. de Laulanié H (1993) Le système de riziculture intensive malgache. Tropicultura 11(3):110-114.

77. Uphoff N (1999) Agroecological implications of the system of rice intensification (SRI) in Madagascar. Environ Dev Sustain 1(3):297-313.

78. Sinclair T (2004) Agronomic UFOs waste valuable scientific resources. Rice Today. Available at: http://ricetoday.irri.org/agronomic-ufos-waste-valuable-scientific-resources/ [Accessed December 10, 2015].

79. Sheehy J., et al. (2004) Fantastic yields in the system of rice intensification: fact or fallacy? Field Crops Res 88(1):1-8.

80. Sheehy JE, Sinclair TR, Cassman KG (2005) Curiosities, nonsense, non-science and SRI. Field Crops Res 91(2-3):355-356.

81. Glover D (2011) The system of rice intensification: time for an empirical turn. NJAS - Wagening J Life Sci 57(3-4):217-224.

82. Ibragimov $\mathrm{N}$, et al. (2007) Water use efficiency of irrigated cotton in Uzbekistan under drip and furrow irrigation. Agric Water Manag 90(1-2):112-120.

83. Hussain I, Hanjra MA (2004) Irrigation and poverty alleviation: review of the empirical evidence. Irrig Drain 53(1):1-15.

84. Burney JA, Naylor RL (2012) Smallholder irrigation as a poverty alleviation tool in sub-Saharan Africa. World Dev 40(1):110-123. 
85. Sne M (1989) Role of extension in irrigation: the Israeli experience. Technological and Institutional Innovation in Irrigation. Proceedings of a Workshop Held at the World Bank April 5-7, 1988. World Bank Technical Paper.

86. ICID (2014) International Commission on Irrigation and Drainage: Annual Report 2013-14 (New Delhi) Available at: http://www.icid.org/ar_e_2013.pdf.

87. Friedlander L, Tal A, Lazarovitch N (2013) Technical considerations affecting adoption of drip irrigation in sub-Saharan Africa. Agric Water Manag 126:125-132.

88. Palanisami K, Mohan K, Kakumanu KR, Raman S (2011) Spread and economics of micro-irrigation in India: evidence from nine states. Rev Agric 46(26 \& 27):81-86. 
Table 1. Summaries of five case studies of interventions to promote innovation for sustainable development.

\begin{abstract}
Artemisinin Combination Therapy for Treating Malaria
Casework by Paul Wilson and Suerie Moon

Artemisinin combination therapy (ACT) is an important drug for treating malaria. The efficacy of artemisinin against malaria, first recorded in the 4th century $A D$, was rediscovered and developed into a modern drug in the 1970 s by scientist Youyou Tu, after the Chinese government prioritized combating malaria during the Vietnam War. Using artemisinin alone renders it vulnerable to the emergence of resistance, so a Chinese and Swiss pharmaceutical firm, Novartis, collaborated to develop a pill in 1992 that combined artemisinin with an older anti-malarial, inventing the first ACT. Novartis initially launched its ACT for the European traveler market in 1998 , but by 2001, NGOs and academics were fiercely criticizing both industry and donors because this effective drug was neither affordable nor available in the poorer countries of sub-Saharan Africa and Southeast Asia where drugresistant malaria was most prevalent (75). Soon after, WHO recommended that governments adopt ACTs for the treatment of malaria, Novartis and WHO agreed to a price for developing countries significantly below the European level, and the Global Fund to Fight HIV/AIDS, Tuberculosis and Malaria (GFATM) agreed to provide funding for these drugs. Drug suppliers in many developing countries began procuring these drugs, but because they were still more expensive than the older, less-effective anti-malarials, uptake was slow. Several years later the Affordable Medicines for Malaria (AMFm) mechanism was created by UNITAID and GFATM to subsidize ACTs to reach more patients and to counteract the emergence of resistance. In the countries where AMFm was tested, end-user uptake of ACTs quickly and significantly increased.
\end{abstract}

\section{Cookstoves for Darfur and Ethiopia}

Casework by Kayje Booker

The Berkeley-Darfur Cookstove (BDS), a biomass-fueled cookstove, was developed by a team of researchers at the Lawrence Berkeley National Lab and the University of California Berkeley (largely through in kind contributions) as a more fuel-efficient alternative to the three-stone open fires used for cooking in the Darfur region of Sudan. The BDS relied on an institutional arrangement in which the entities in charge of stove design and testing, the manufacturer in India, and the NGO managing assembly and distribution on the ground in Darfur, were linked and coordinated through a single organization: the Darfur Stoves Project (DSP). Transnational institutions (Oxfam America, Impact Carbon, and USAID) have played key roles by acting as the boots on the ground in Darfur, coordinating local distribution, and providing funding for stove development and adoption. DSP has also adapted the technology for use in Ethiopia (31).

\section{Drip Irrigation}

Casework by Alicia Harley and Lonia Friedlander

Drip irrigation is a technology for irrigating plants that reduces water requirements and improves the water use efficiency of many crops (82). In addition, drip irrigation has been found to improve yields and decrease labor requirements, raising incomes for farmers and potentially helping poor farmers escape poverty $(83,84)$. Modern drip irrigation methods were invented in Israel in the 1960s (85). In Israel as well as other developed countries like Spain, Italy and the United States adoption of drip irrigation has been widespread (86). However, adoption of drip irrigation amongst developing countries especially in Sub-Saharan Africa remains very low and faces many barriers including lack of water storage facilities and destruction of drip equipment by wildlife (87). In spite of the challenges for drip irrigation in much of the developing world, in the past 12 years certain states in India, including Andhra Pradesh and Gujarat, have achieved remarkable success in farmer adoption of the technology $(86,88)$. The case shows how the success of drip irrigation in India was built on a unique subsidy policy first designed by government bureaucrats in Andhra Pradesh and later modified across many states in India, which aligned the incentives of private sector actors with public goals while lowering the cost of the technology to end-users.

\section{System of Rice Intensification for Rice Growing Casework by Alicia Harley}

The System of Rice Intensification (SRI), a practice-based technology for improving rice yields and decreasing seed and fertilizer inputs, was developed in Madagascar in the 1980 s by a French Jesuit priest working in close collaboration with local NGOs and farmers (76). In the mid-1990s, Norman Uphoff, a professor at Cornell University, learned about SRI in Madagascar, and after three years of on-farm evaluations, he began championing SRI as a promising technology for improving rice yields for small farmers (77). Uphoff fostered a global network of academics and civilsociety partners who have promote the technology. Initially, SRI met significant pushback from the established rice research community, who called the practice "agronomic UFOs," or unconfirmed field observations (78-80). While tensions over the efficacy of SRI persist, many actors including Oxfam and the World Bank as well as government programs and policies in India, China, Indonesia and Vietnam promote SRI as an important technology for helping small farmers increase yields and decrease their input costs. SRI has been tried by farmers in 60 countries and has achieved more widespread farmer adoption and some countries including Cambodia, India and Vietnam. The case highlights the role and challenge of technology selection for sustainable development where end-user needs are complex, varied and often hard to translate into research settings (81).

\section{Ceramic Pot Water Filters for Household Water Treatment}

Casework by Mark Williams, Sharmila Murthy, Daniele Lantagne, and Lucilla Spini

Ceramic pot filters (CPFs) are a Household Water Treatment and Storage (HWTS) technology designed to treat contaminated water at home. The CPF is a porous ceramic pot that allows water but not bacteria and parasites to pass through to a container below. CPFs are a cost-effective and simple-touse treatment option, especially for water with medium to high turbidity. They do not require power or chemicals and can be produced locally, which can provide additional benefits to the community. The production of CPFs, however, faces barriers related to the lack of capacity, production standards, and physical infrastructure. Sustained use is challenged by barriers related to the access to information, behavioral change, maintenance, cost and commercial appeal. Key insights include the need to develop generalizable production standards, to promote more user-friendly products, and to assess the actual impact of HWTS interventions, including those that rely on CPFs.

\section{Industrial Symbiosis}

Casework by Dwayne Appleby, Kira Matus and Vanessa Timmer

Industrial symbiosis (IS) is an approach to establishing and building relationships among businesses to optimize resource use and reduce burdens on the environment and human health. Based on a biological systems metaphor, IS redefines waste as a resource and shifts industrial production towards a circular economy. An IS network links a variety of different firms, usually in close geographical proximity. Businesses in an industrial cluster share and exchange waste materials, energy, and water and often collaborate on business services such as technical expertise, cleaning, security, and transportation. Through a number of social and technological innovations, these linkages improve the environmental and social impacts of manufacturing activity. The waste, idle time, and abandoned byproducts from one company becomes raw material for another company, increasing resource and energy use, and minimizing waste discharge, ideally by diverting waste from landfill. The practice of IS has been growing around the world including in Kwinana (Australia), Ulsan (South Korea) and EcoTEDA (Tianjin, China) and in the UK with the National Industrial Symbiosis Programme (NISP-UK). In all of these cases, the development of social bonds among participants was crucial for the growth of the program. NISP-UK created a standardized set of procedures, particularly for linking small and medium-sized enterprises (SMEs) and supports NISP efforts in more than 20 countries. The modularity of IS approaches, its adaptation to local contexts, the support of facilitative bodies such as NISP, and the development of favorable policies, such as an increased cost of waste disposal, are contributing to the spread of IS in various locations around the world. 


\section{Supporting Information}

This perspective draws on our experience leading a multi-year research initiative at the Harvard Kennedy School that commissioned eighteen original case studies. In particular, Figure 1 of the manuscript highlights findings from five cases that were particularly illustrative of how innovation systems operate, and what interventions can be made to re-align them towards sustainable development. In this supplementary information, we provide expanded details on these five case studies, each of which is available in expanded working papers and published papers, as referenced below.

\section{Artemisinin Combination Therapy for Treating Malaria}

\section{Casework by Paul Wilson and Suerie Moon}

An expanded treatment of this case study is available in Moon, 2009 (1) and as a working paper: Wilson, 2016 (2).

Artemisinin combination therapies (ACTs) are a relatively new class of drugs for treating malaria. Older malaria treatments such as chloroquine (CQ) introduced in the 1940's had become less effective due to the development of resistance in malaria parasites. Resistance spread globally over just a few years and by the 1990's had rendered CQ largely useless against falciparum malaria in most places $(3,4)$. The world was faced with the prospect of having no effective and practical treatment for malaria. Fortunately, a new class of drugs was just then becoming available-artemisinin and its derivatives.

The efficacy of artemisinin against malaria, first recorded in the 4th century AD, was rediscovered and developed into a modern drug in the 1970s by scientist Youyou Tu, after the Chinese government prioritized combating malaria during the Vietnam War $(5,6)$. Using artemisinin alone renders it vulnerable to the emergence of resistance, so a Chinese and Swiss pharmaceutical firm, Novartis, collaborated to develop a pill in 1992 that combined artemisinin with an older anti-malarial (lumefantrine), inventing the first ACT. Novartis initially launched its ACT for the European traveler market in 1998, but by 2001, NGOs and academics were fiercely criticizing both industry and donors because this effective drug was neither affordable nor available in the poorer countries of sub-Saharan Africa and Southeast Asia where drug-resistant malaria was most prevalent. Soon after, WHO recommended that governments adopt ACTs for the treatment of malaria, Novartis and WHO agreed to a price for developing countries significantly below the European level, and the Global Fund to Fight HIV/AIDS, Tuberculosis and Malaria (GFATM) agreed to provide funding for these drugs. Drug suppliers in many developing countries began procuring these drugs, but because they were still more expensive than the older, less-effective anti-malarials, uptake was slow. (1)

Achieving widespread use of ACTs presented a formidable challenge. ACTs are more expensive to produce than CQ and other commonly used antimalarials. The higher cost would prevent many poor people from purchasing ACTs despite evidence of the ineffectiveness of older drugs. This challenge was compounded by the weak public health systems in many of the countries most affected by malaria. Moreover, experts believed that reducing the manufacturing costs of ACTs through economies of scale was probably not possible and that their $\$ 1.00$ per course price tag was unlikely to come down due to the complexities of the manufacturing process. (2) 
In order to overcome the barriers to widespread use of ACTs, a committee of the US Institute of Medicine (IOM) led by Stanford economist Kenneth Arrow originally conceived of the institutional intervention that would come to be known as the Affordable Medicines Facility-malaria (AMFm). The committee's central recommendation, made in 2004, was the establishment of a global donor-funded ACT subsidy. The goal of a subsidy would be to make ACTs available at prices similar to those for CQ and other monotherapies, thereby permitting broad access and "pricing out" the monotherapies. The subsidy would apply not only to government purchases, but also to the private sector. The IoM Committee hoped that by relying on existing distribution channels, especially the informal private sector of largely unregulated sellers and village shops, ACTs would be both affordable and widely available and drive out the lesseffective incumbent technologies (7).

Five years later the Affordable Medicines for Malaria (AMFm) mechanism was created by two global health funding bodies, UNITAID and GFATM. A two-year pilot program was officially launched in April 2009 in eight countries. While the Arrow committee had recommended a global, all-at-once initiative, other actors were skeptical and wanted a more rigorous testing of the subsidy before rolling it out at a larger scale. Outcomes from the pilot were mixed: while the price of ACTs to end-users did fall significantly, including in hard-to-reach rural areas, consumers did not adopt ACTs as quickly or as thoroughly as hoped and ACTs did not completely capture the market from CQ and other mono-therapies. Dedicated financing for the AMFm pilot was discontinued, but some of the pilot countries continued using other donor funds to sustain the subsidy. (2)

Today, the challenge of ensuring access to ACTs in malaria-endemic regions and controlling the spread of resistance remains formidable. The ACT experience, however, has spurred important institutional changes: it highlighted the potential human benefits of developing new technologies for diseases that primarily affect the poor; it challenged the prevailing norm that donors should not finance the provision of advanced technologies in developing countries for fears such programs would not be sustainable; and it provided significant evidence on the possibilities and limits of global subsidies as a policy tool.

\section{System of Rice Intensification for Rice Growing}

\section{Casework by Alicia Harley}

An expanded treatment of this case study is available as a working paper: Harley, 2016 (8).

The System of Rice Intensification (SRI), a practice-based technology for improving rice yields and decreasing seed and fertilizer inputs, was developed in Madagascar in the 1980s, by a French Jesuit priest working in close collaboration with local NGOs and farmers (9). In the mid-1990s, Norman Uphoff, a professor at Cornell University, learned about SRI in Madagascar, and after three years of on-farm evaluations, he began championing SRI as a promising technology for improving rice yields for small farmers (10). Uphoff fostered a global network of academics and civil-society partners who promoted the technology. Initially, SRI met with significant pushback from the established rice research community, who called the practice "agronomic UFOs," or unconfirmed field observations (11-13). While tensions over the efficacy of SRI persist, many actors including Oxfam and the World Bank as well as government programs and policies in India, China, Indonesia and Vietnam promote SRI as an important technology for helping small farmers increase yields and decrease input costs. SRI has been tried by farmers in 60 
countries and has achieved widespread farmer adoption in several countries including Cambodia, India and Vietnam.

This case looks first at the invention and selection of SRI in Madagascar and the development of a global network of scholars and practitioners, who worked through a nested-multi level structure to promote adoption of SRI by farmers and published over 650 peer reviewed articles evaluating the agronomic, economic and social dimensions of SRI between 2000 and 2015. In parallel, the case looks at the critiques of SRI, from the established rice research community including scholars at the International Rice Research Institute (IRRI) and other established research centers. The case disentangles the evolving language with which the two communities framed the terms of the debate and the role of NGOs and development organizations such as Oxfam in creating legitimacy for SRI in the development community. Finally, the case grounds the analysis on the adoption of SRI in Bihar, an Indian state. In 2011, the state government of Bihar selected the technology for inclusion in the official agriculture road map, despite continued controversy between different actors at the state and national level.

Across Bihar, interviews with farmers as well as government extension officers, policy makers and agriculture scientists confirm that a significant majority of state level actors agree that SRI does increase yields with respect to traditional practices. Where these actors disagree however is in translating these yield increases into calculation of farm revenues, due to disagreements in the extra labor demanded by SRI as well as the rate at which labor is priced in these calculations. Agriculture scientists tend to use a common government wage rate set by the national employment guarantee scheme (MGNREGA) as a proxy to calculate profits from different technologies and practices in research station experiments. Yet in reality, MGNREGA work is limited at the village level and farmers are often paid significantly lower wages for non-MGNREGA labor.

At the same time, SRI is not the silver bullet for small and marginal farmers often portrayed by proponents of the technology. Fundamental to the practice of SRI is timely access to irrigation. While overall, SRI decreases water requirements; the practice is also highly sensitive to timely availability of water during the planting cycle. Farmers, who are exclusively dependent on monsoon rains, are often limited in their ability to practice SRI. In drought prone South Bihar, this has been a major roadblock to SRI adoption. The complex relationship between SRI, a technology that reduces water requirements, and the need for timely availability of water resources is often poorly understood by proponents of the technology especially at higher decision making levels (e.g. national and transnational).

The case highlights the hidden role of selection as an important stage in the innovation system, especially with respect meeting the needs of vulnerable populations, where end-user needs are complex, varied and often hard to translate into experimental designs conducted on agriculture research stations. This finding has implications for the selection of technologies to meet sustainable development goals. Technologies with the potential to meet the needs of vulnerable populations should be evaluated with a more nuanced understanding of the specific opportunities and constraints faced by end-users. Improving the ways in which the agriculture research community evaluates technologies to include a deeper understanding of the objective functions facing different categories of farmers would go a long way in ameliorating the controversy over SRI. A more nuanced understanding could also improve policy design and implementation of programs meant to support farmer adoption. 


\section{Cookstoves for Darfur and Ethiopia}

\section{Casework by Kayje Booker}

An expanded treatment of this case study is available as a working paper: Booker, 2016 (14).

The International Energy Agency estimates that 2.7 billion people use traditional solid biomass fuels (wood, dung and other biomass) for cooking (14). Use of inefficient biomass stoves is understood to contribute to local deforestation as well as climate change and is a major public health threat in the developing world: 4.3 million deaths per year in 2012 are attributable to household air pollution (15), largely caused by products of incomplete combustion resulting from cooking. Because each of these problems could be mitigated by increasing the fuel-efficiency of cookstoves, developing such improved cookstoves has attracted attention for decades (16).

Within this context, Dr. Ashok Gadgil, a researcher at the Lawrence Berkeley National Lab (LBL) was approached by the US Agency for International Development (USAID) to develop a cookstove for Internally Displaced Person (IDP) camps in Darfur (Sudan) that could replace the traditional three-stone open fire with one that could use kitchen waste in place of fuelwood (17). USAID was concerned with cookstoves because women in the refugee camps were getting systematically raped while walking long distances to gather firewood (18). After visiting Darfur in 2005, Dr. Gadgil and his team at LBL and the University of California Berkeley (UC Berkeley), with collaboration from Engineers Without Borders, started developing a metal-based cookstove adapted from an Indian "Tara” cookstove named. The result was the Berkeley-Darfur Cookstove (BDS) (17), a biomass-fueled cookstove that was a 50\% more fuelefficient (as measured by various cooking tests) than the three-stone open fires traditionally used for cooking (19).

According to Dr. Gadgil, around 150 people were involved in developing the BDS by 2008, many of them providing in-kind donations. The costs, not accounting for time donated, were mostly funded by private donations and USAID grants and reached around \$300,000 in 2008. A large number of actors contributed to developing the BDS after 2008, including private donations and support from U.C. Berkeley's Blum Center and the Sustainable Products and Services Program (17). Dr Gadgil also worked with LBL's technology transfer office to patent the stove in order to incentivize investor interest, generate small revenues for LBL to continue the work in this area, and protect the brand from lower quality copies that may hamper its longer-term widespread use (17). To facilitate and coordinate the non-technical aspects of BDS production and dissemination, Dr. Gadgil helped found the Darfur Stoves Project (DSP), an NGO, which licensed the stove from LBL and worked in close collaboration with the Lab and partners on the ground in India and Darfur.

From the beginning of the project in 2005, Dr. Gagdil and his collaborators recognized that ensuring that the stove was culturally appropriate was essential for successful adoption. This led to a BDS that was adapted 14 times (it went through 14 versions) as of 2014. Nevertheless, because the cookstove cost \$16 to produce and deliver to the camp, it was too expensive for most refugee families to pay upfront, even though the payback period is less than 20 days (19). Thus, widespread cookstove distribution required financial support from external actors. 
Recently, the emergence of carbon markets through the Clean Development Mechanism (CDM) has spurred some investor interest in cookstoves. In late 2008, World Vision International, a large NGO contacted Dr. Gadgil to explore the possibility of adapting the BDS for use in Ethiopia (20). The Ethiopian project would be supported by funding from an international investor seeking CDM carbon credits. A grant from the US Department of Energy that was matched by World Vision International (which had transferred the project to World Vision Australia), enabled LBL to adapt the BDS to better match Ethiopian cuisine and cultures (19). Current work involves developing a CDM-compliant cookstove pilot program which includes the commercialization, dissemination, and monitoring of 1000 Berkeley Ethiopian Stoves (20). This work is being tracked by another NGO (Potential Energy, the new and expanded NGO that was formerly Darfur Stoves Project), which is working on a full launch after the LBL pilot (20). This case illustrates not only the multiplicity and multi-level nature of the actors, but also the non-linearity of innovation, the need for adaptation and long time scales involved even in this type of technology, which may be perceived by many as mundane or non-complex.

\section{Ceramic Pot Water Filters for Household Water Treatment}

Casework by Mark Williams, Sharmila Murthy, Daniele Lantagne, and Lucilla Spini

An expanded treatment of this case study is available as a working paper: Williams, et al., 2016 (21).

Where infrastructure barriers prevent the effective delivery of clean drinking water through centralized systems, household water treatment and storage systems (HWTS) can be an effective interim solution that enables users to treat the water in their homes and thereby reduce the incidence of water-borne diseases. As the name suggests, HWTS enable individual users to treat water at home. The need for safe drinking water, especially in developing countries, is clear. The WHO and UNICEF estimate that as of 2015, 663 million people still used unimproved water sources, which include unprotected wells, springs, and surface water. An additional 1.2 billion people are estimated to drink contaminated water from so-called “improved" sources (22). Due in large part to unsafe drinking water, diarrhea is the second leading cause of death among children under five globally, with an estimated 1.5 million deaths per year (23).

This case examines the benefits and limitations of one specific type of HWTS, the ceramic pot filter (CPF). First developed in early nineteenth century England (24), the porous ceramic pot allows water but not bacteria and protozoa to pass through to a container below. NGOs and dedicated individuals, with varying degrees of support from universities and aid organizations, have played leading roles in manufacturing and distributing CPFs. As a result of research conducted by Dr. Fernando Mazariegos of Guatemala and funded by the Inter-American Development Bank in the 1980s, CPFs are now impregnated with colloidal silver to prevent the growth of bacteria, slime and other contaminants on the filter wall (25). In addition, two members of the NGO Potters for Peace, Ron Rivera and Professor Manny Hernandez of Northern Illinois University, are credited with further improving the manufacturing process $(26,27)$.

CPFs are a cost-effective method for reducing the protozoal and bacterial organisms that cause many water-borne diseases $(10,11,14-16)$

. Compared to other HWTS technologies, CPFs are often better equipped to treat water with medium to high turbidity (i.e. water with particulate matter (31)). CPFs do not require electricity and can be manufactured with local materials and labor. Because CPFs do not require the addition of chemicals, the 
treatment process does not change the taste or smell of the water. As a result, some studies have reported strong uptake and continued usage of CPFs $(31,32)$.

Despite their numerous benefits, CPFs also have their drawbacks. As one World Health Organization study observed, “[q]uality control, breakage in transport or cleaning, high up-front cost, slow flow rates, the need for regular cleaning and susceptibility to water recontamination are challenges that may inhibit scaling up this alternative” (24). Sustained adoption can also be challenging to achieve because the intended recipients may not recognize the need for treating water (24). This is not unique to the water sector; uptake of any environmental health intervention can be difficult where traditional behavior needs to change (24). Cost is another limitation. Even where NGOs are able to provide CPFs for free, replacement parts are often unavailable or too expensive for the user to purchase (33). Moreover, local CPF manufacturing efforts can be difficult to scale up (24). The zeal and enthusiasm that donors and aid agencies have traditionally shown for HWTS, like CPFs, needs to be critically examined to assess the true impact of these projects. Key insights include the need to develop generalizable production standards, to promote more user-friendly products, and to assess the actual impact of HWTS interventions, including those that rely on CPFs.

\section{Drip Irrigation}

\section{Casework by Alicia Harley and Lonia Friedlander}

An expanded treatment of this case study is available as a working paper: Harley and Friedlander, 2016 (34).

Drip irrigation is a technology for irrigating plants that reduces water requirement and improves the water use efficiency of many crops (35). In addition, drip irrigation improves yields and decreases labor requirements, raising incomes for farmers and potentially helping poor farmers escape poverty (36, 37). Modern drip irrigation methods were invented in Israel in the 1960s and government support through regulations, subsidies and capacity building programs fostered widespread use (38, 39). Outside Israel, other developed countries including Spain, Italy and the United States have seen widespread adoption of drip irrigation technologies (40). However, adoption of drip irrigation among developing countries especially in Sub-Saharan Africa remains very low and faces many barriers including high upfront costs to small farmers, lack of farmer capacity, limited agricultural support and extension services, lack of water storage facilities and destruction of drip equipment by wildlife (41).

In spite of the barriers in the innovation system for drip irrigation in much of the developing world, India has achieved remarkable success in adoption and widespread use of the technology $(42,43)$. This case looks at the reasons for India's success in fostering widespread use of drip irrigation, focusing on the institutional design of India's subsidy support program.

In India, the first experiments with drip irrigation on agriculture research stations began in the 1970s. By the 1980s, India had its own homegrown drip irrigation company, Jain Irrigation Systems Ltd. Despite this, adoption of drip irrigation was slow to take off(41, 42). Many barriers prevented higher adoption rates including the upfront capital costs of the technology for India's small farmers (the average landholding size in India is 1.2 hectares). In addition, lack of farmer awareness about the potential benefits of the technology and weak agricultural extension services created barriers to farmer adoption.

The slow pace of drip irrigation adoption in India changed rapidly in 2003, when the southeastern state of Andhra Pradesh (AP) developed a unique subsidy program to promote the technology. In 2003, the Chief 
Minister of the State of AP faced an upcoming election, extreme drought and an unhappy electorate. In response, he convened a working group tasked with the responsibility of finding a way to effectively promote drip irrigation. Based on the recommendations of the working group, the state developed the Andhra Pradesh Micro Irrigation Project (APMIP) to support drip irrigation adoption. On the surface, APMIP was designed as a downstream subsidy program that changed the prices farmers faced for drip irrigation equipment. The design of the APMIP policy also included two unique institutional elements. First, the government used the subsidy program as a carrot to leverage the private sector to reduce the component-wise costs of their systems. Second, the design of the program incentivized the private sector to assume significant responsibility for technology demonstration, farmer training and after sale service. By using the subsidy program to incentivize responsibility for farmer outreach and capacity building to the private sector, the government overcame a major barrier to widespread use of drip irrigation.

The APMIP program was highly successful. In the initial year, APMIP hit its target of bringing one hundred thousand hectares under drip irrigation (only five hundred thousand hectares of area had been brought under drip irrigation in India in the previous thirty three years) (46). Based on AP's success, the Government of India created a Centrally Sponsored Scheme for Micro Irrigation in 2005 that extended the subsidy policy across the country(42). After 2005, overall adoption rates in India increased and by the end of 2008, the technology irrigated 1.4 million hectares of land (45). By 2010, India had the single largest area under drip irrigation globally, though the fraction of drip compared to total irrigated area was still quite low at $3.12 \%$ of total irrigated land $(42,43)$.

The case demonstrates how the success of drip irrigation in India was built on a unique subsidy policy first designed by government bureaucrats in Andhra Pradesh and later modified across many states in India. This program aligned the incentives of private sector actors with public goals while lowering the cost of the technology to end-users. Despite the success of India's subsidy program for drip irrigation, many challenges remain. First, while adoption rates have been very high in some states, in other states, adoption has lagged despite the subsidy program. One key reason for low adoption rates in some states is poor administration of the subsidy program at the state level, in addition to poor extension services and agro-ecological considerations. A second critical challenge is that rates of adoption by small and marginal farmers (those with less than less than 2 hectares) remain low (42). This is at least partly because private sector companies have little incentive to market to small farmers, as the profit per farmer is small compared to the effort required. Finally, the technology standards set by the subsidy policy, excludes low cost drip irrigation systems and disincentive companies to experiment with lower cost technology options that might prove more appropriate for the needs of small and marginal farmers.

\section{Industrial Symbiosis}

\section{Casework by Dwayne Appleby, Kira Matus, and Vanessa Timmer.}

An expanded treatment of this case study is available as a working paper: Appleby, 2016 (47).

While industrial production provides an important economic basis for improved livelihoods, its impacts places a significant burden on environmental and human health. Industrial symbiosis (IS) is one method for shifting industrial production and consumption systems toward a more circular model. Based on a biological systems metaphor, IS views the waste or byproducts from one activity as sources of inputs for another (48). 
In practice, IS links a variety of different firms, usually in close geographical proximity. Through a number of social and technological innovations, these linkages improve the environmental and social impacts of manufacturing activity. Innovations that have emerged from IS include material and energy flow analysis tools and techniques, new processes and equipment for byproduct exchanges, and sharing arrangements for human and other social resources (47).

The practice of IS has been growing around the world, and this case looks at four IS efforts: Kwinana (Australia), the National Industrial Symbiosis Programme (NISP-UK), Ulsan (South Korea) and EcoTEDA (Tianjin, China). Kwinana is an example of an 'emergent' IS program, which emerged without outside intervention; the other three were 'goal-oriented'- specifically planned, with a number of policy interventions from their start.

Despite the differences in geography and origin, these four examples provide important insights into the broad innovation system surrounding IS. In all of these cases, the development of social bonds between participants was crucial for program success. These bonds serve as the backbone for resource exchange networks, and were facilitated by central coordinating organizations. Facilitators help with identification, planning, implementation and adaptation of exchanges among participating firms (49-52).

Like most IS projects, these cases drew on international sources of expertise. NISP has, in fact, become a major IS consultant, acting as a hub and conduit between UK-derived and international experiences. In addition to NISP, SWITCH-Asia Programme helped start the EcoTEDA program (53). The combination of available information, a set of standardized procedures, and the modularity of the platform, which allows for adaptation to local technological, social, and political contexts, have all contributed to the spread of IS from developed to developing world contexts (47).

While facilitating bodies have proven crucial for the success of IS projects, the primary driver of participation in industrial symbiosis is the economic benefits derived by participants. Thus, across examples, underlying policy environments are important in either favoring incumbent technologies or providing economic incentives for innovation (54). For example, where waste disposal costs and environmental regulations are relatively low, IS uptake is negatively impacted. Conversely, where waste disposal costs are high and environmental regulations more rigorous and difficult to avoid, the financial benefits of IS incentivize participation (47). More generally, policies that change the relative costs of inputs and/or outputs can drive the uptake of IS.

Some concern exists that if IS networks become too robust, it can result in technological lock-in, with firms declining to reduce waste or to adopt newer, more sustainable technologies because of the profits accruing from existing IS exchanges. There is little evidence to support this hypothesis. Furthermore, many exchanges are centered around human resources, which do not involve large amounts of sunk capital. There are also open questions as to whether IS projects deliver social and livelihood benefits, and only limited data on environmental impacts, as many of the projects do not engage in rigorous monitoring and reporting.

IS activities need to be economically attractive, and there is also a need to support a facilitating or coordinating body which requires stable sources of revenue. Grant-funded and government-supported programs have both had to explore alternative resource streams. For example, NISP, after its government funding ended, is now consulting on IS development in different countries. Beyond funding streams, the 
networks in any IS program must also be large enough that it is robust to changes in circumstance and resource streams.

Overall, this case demonstrates variable success across IS projects over time, but also some of the key ways that different actors and policy interventions have been able to overcome different challenges that emerge. 


\section{Supporting Information References}

1. Moon S (2009) Medicines as global public goods: the governance of technological innovation in the new era of global health. Glob Health Gov II(2). Available at:

http://www.ghgj.org/Moon_Medicines\%20as\%20Global\%20Public\%20Goods.pdf.

2. Wilson P (2016) The Affordable Medicines Facility for Malaria: implications for malaria treatment and access other new technologies (Sustainability Science Program, Harvard University, Cambridge, MA).

3. Payne D Spread of chloroquine resistance in plasmodium falciparum. Parasitol Today 3(8):241-246.

4. Klein EY (2013) Antimalarial drug resistance: a review of the biology and strategies to delay emergence and spread. Int J Antimicrob Agents 41(4):311-317.

5. Tu Y (2011) The discovery of artemisinin (qinghaosu) and gifts from Chinese medicine. Nat Med 17(10):1217-1220.

6. Honigsbaum M (2001) The Fever Trail: In Search of the Cure for Malaria (Farrar, Straus and Giroux, New York).

7. Arrow KJ, Panosian C, Gelband H, Institute of Medicine (U.S.) eds. (2004) Saving Lives, Buying Time: Economics of Malaria Drugs in an Age of Resistance (National Academies Press, Washington, D.C).

8. Harley A (2016) The System of Rice Intensification for Improving Rice Yields: The Hidden Role of Technology Selection for Meeting the Needs of Vulnerable Populations (Sustainability Science Program, Harvard University, Cambridge, MA).

9. de Laulanié H (1993) Le système de riziculture intensive malgache. Tropicultura 11(3):110-114.

10. Uphoff N (1999) Agroecological implications of the system of rice intensification (SRI) in Madagascar. Environ Dev Sustain 1(3):297-313.

11. Sinclair T (2004) Agronomic UFOs waste valuable scientific resources. Rice Today. Available at: http://ricetoday.irri.org/agronomic-ufos-waste-valuable-scientific-resources/ [Accessed December 10, 2015].

12. Sheehy J., et al. (2004) Fantastic yields in the system of rice intensification: fact or fallacy? Field Crops Res 88(1):1-8.

13. Sheehy JE, Sinclair TR, Cassman KG (2005) Curiosities, nonsense, non-science and SRI. Field Crops Res 91(2-3):355-356.

14. IEA (2015) World Energy Outlook 2015 (OECD Publishing) Available at: http://www.oecdilibrary.org/energy/world-energy-outlook-2015_weo-2015-en [Accessed December 10, 2015].

15. World Health Organization (2014) Burden of disease from Household Air Pollution for 2012 Available at: who.int/phe/health_topics/outdoorair/databases/HAP_BoD_results_March2014.pdf [Accessed December 10, 2015]. 
16. World Bank (2011) Household Cookstoves, Environment, Health, and Climate Change: A New Look at an Old Problem (Washington, D.C.) Available at:

http://documents.worldbank.org/curated/en/2010/03/14600224/household-cook-stoves-environmenthealth-climate-change-new-look-old-problem [Accessed December 10, 2015].

17. Booker KM, Gadgil AJ, Winickoff DE (2012) Engineering for the global poor: the role of intellectual property. Sci Public Policy 39(6):775-786.

18. Tsai AC, et al. (2012) Medical Evidence of Human Rights Violations against Non-Arabic-Speaking Civilians in Darfur: A Cross-Sectional Study. PLoS Med 9(4):e1001198.

19. Booker K (2016) Berkeley Darfur Cookstove: Case Study (Sustainability Science Program, Harvard University, Cambridge, MA).

20. Lawrence Berkeley National Laboratory (2015) Cookstove Projects - Ethiopia. Available at: http://cookstoves.lbl.gov/ethiopia.php [Accessed December 10, 2015].

21. Williams M, Murthy S, Lantagne D, Spini L (2016) Access to Safe Water: An Analysis of Ceramic Water Filters (Sustainability Science Program, Harvard University, Cambridge, MA).

22. Onda K, LoBuglio J, Bartram J (2012) Global Access to Safe Water: Accounting for Water Quality and the Resulting Impact on MDG Progress. Int J Environ Res Public Health 9(12):880-894.

23. UNICEF, Organización Mundial de la Salud (2009) Diarrhoea: why children are still dying and what can be done (United Nations Children's Fund, New York).

24. Clasen T (2009) Scaling Up Household Water Treatment Among Low-Income Populations (World Health Organization) Available at:

http://www.who.int/household_water/research/household_water_treatment/en/.

25. Lantagne D (2001) Investigation of the Potters for Peace Colloidal Silver Impregnated Ceramic Filter - Report 1: Intrinsic Effectiveness Available at: http://web.mit.edu/watsan/Docs/Other\%20Documents/ceramicpot/PFP-Report1Daniele\%20Lantagne,\%2012-01.pdf.

26. Potters for Peace | Our common language is clay. Available at: http://pottersforpeace.com/ [Accessed December 16, 2015].

27. Sorbett S (2008) Solution in a Pot - The New York Times. $N$ Y Times Mag. Available at: http://www.nytimes.com/2008/12/28/magazine/28rivera-t.html?emc=eta1\&_r=1 [Accessed December 16, 2015].

28. Brown J, Chai R, Wang A, Sobsey MD (2012) Microbiological Effectiveness of Mineral Pot Filters in Cambodia. Environ Sci Technol 46(21):12055-12061.

29. Brown J, Sobsey M (2006) Independent Appraisal of Ceramic Water Filtration Interventions in Cambodia: Final Report.

30. Lantagne D (2001) Investigation of the Potters for Peace Colloidal Silver Impregnated Ceramic Filter - Report 2: Field Investigations Available at: 
http://web.mit.edu/watsan/Docs/Other\%20Documents/ceramicpot/PFP-Report2-

Exec\%20Sum,\%20DanieleLantagne,\%2012-01.pdf.

31. Sobsey MD, Stauber CE, Casanova LM, Brown JM, Elliott MA (2008) Point of use household drinking water filtration: a practical, effective solution for providing sustained access to safe drinking water in the developing world. Environ Sci Technol 42(12):4261-4267.

32. UNICEF (2007) Improving Household Drinking Water Quality: Use of Ceramic Water Filters in Cambodia (UNICEF Water and Sanitation Program) Available at:

http://www.unicef.org/eapro/WSP_UNICEF_FN_CWP_Final.pdf [Accessed December 16, 2015].

33. Desmyter D, Adagwine AP, Ibrahim S, Jackson MK, Murcott SE (2009) Monitoring and Evaluation of 1,000 Households receiving Ceramic Pot (Kosim) Filters after an Emergency Flood Mass Distribution in Northern Ghana (Atlanta, GA).

34. Harley A, Friedlander L (2016) Innovation and Access to Technologies for Sustainable Development: A Case Study of the Drip Irrigation in India (Sustainability Science Program, Harvard University, Cambridge, MA).

35. Ibragimov N, et al. (2007) Water use efficiency of irrigated cotton in Uzbekistan under drip and furrow irrigation. Agric Water Manag 90(1-2):112-120.

36. Hussain I, Hanjra M (2004) Irrigation and poverty alleviation: review of the empirical evidence. Irrig Drain 53(1):1-15.

37. Burney JA, Naylor RL (2012) Smallholder Irrigation as a Poverty Alleviation Tool in Sub-Saharan Africa. World Dev 40(1):110-123.

38. Sne M (1989) Role of extension in irrigation: the Israeli experience. Technological and Institutional Innovation in Irrigation. Proceedings of a Workshop Held at the World Bank April 5-7, 1988. World Bank Technical Paper.

39. Fischhendler I (2008) Institutional conditions for IWRM: the Israeli case. Groundwater 46(1):91102.

40. ICID (2014) International Commission on Irrigation and Drainage: Annual Report 2013-14 (New Delhi).

41. Friedlander L, Tal A, Lazarovitch N (2013) Technical considerations affecting adoption of drip irrigation in sub-Saharan Africa. Agric Water Manag 126:125-132.

42. Palanisami K, Mohan K, Kakumanu KR, Raman S (2011) Spread and economics of micro-irrigation in India: evidence from nine states. Rev Agric 46(26 \& 27):81-86.

43. ICID (2014) International Commission on Irrigation and Drainage: Annual Report 2013-14 (New Delhi) Available at: http://www.icid.org/ar_e_2013.pdf.

44. Goldberg RA, Knoop C-I, Preble M (2011) Jain Irrigation Systems Limited: More Crop Per Drop. Harv Bus Sch Case (N9-911-419). 
45. Bhamoriya V, Mathew S (2014) An Analysis of Resource Conservation Technology : A Case of Micro-Irrigation System (Ahmedabad).

46. Bhamoriya V, Mathew S (2014) An Analysis of Resource Conservation Technology: A Case of Micro-Irrigation System (Drip Irrigation) (Centre for Management in Agriculture Indian Institute of Management, Ahmedabad, India) Available at:

http://www.iimahd.ernet.in/users/webrequest/files/cmareports/15Analysis_Resource_Final.pdf [Accessed December 17, 2015].

47. Appleby D (2016) The Industrial Symbiosis Innovation System: A Case Study (Sustainability Science Program, Harvard University, Cambridge, MA).

48. Harris S (2007) Industrial symbiosis in the Kwinana industrial area (Western Australia). Meas Control 40(8):239-244.

49. Dhanaraj C, Parkhe A (2006) Orchestrating innovation networks. Acad Manage Rev 31(3):659-669.

50. Chertow M, Ehrenfeld J (2012) Organizing Self-Organizing Systems. J Ind Ecol 16(1):13-27.

51. Yu C, Dijkema GP, Jong M (2014) What Makes Eco-Transformation of Industrial Parks Take Off in China? J Ind Ecol.

52. Paquin RL, Howard-Grenville J (2012) The evolution of facilitated industrial symbiosis. J Ind Ecol 16(1):83-93.

53. Shi H, Chertow M, Song Y (2010) Developing country experience with eco-industrial parks: a case study of the Tianjin Economic-Technological Development Area in China. J Clean Prod 18(3):191199.

54. Park H-S, Rene ER, Choi S-M, Chiu AS (2008) Strategies for sustainable development of industrial park in Ulsan, South Korea-from spontaneous evolution to systematic expansion of industrial symbiosis. J Environ Manage 87(1):1-13. 